\title{
LITERASI VISUAL: AKTUALISASI PEMBELAJARAN SASTRA MELALUI FILM
}

\author{
Kelik Agung Cahya Setiawan and Apri Damai Sagita Krissandi \\ Universitas Negeri Yogyakarta \\ kelikagung.2017@student.uny.ac.id,apridamai@gmail.com \\ DOI: doi.org/10.24071/snfkip.2018.18 \\ Diterima 27 September 2018; diterbitkan 21 Desember 2018
}

\begin{abstract}
Abstrak
Berbagai perkembangan media hiburan sudah banyak bemunculan. Salah satu dari media hiburan adalah film. Tujuan dari penelitian ini adalah memahami sejauhmana aktualisasi pembelajaran film khususnya film "Dilan 1990" menjadi media mengakrapkan peserta didik terhadap karya sastra. Hasil dari penelitian ini adalah Film dapat digunakan sebagai suatu media dalam mengakrabkan sastra kepada peserta didik efektif dan efisien untuk menubuhkan kearaban peserta didik terhadap karya sastra dengan berbagai perbedaan gaya belajar peserta didik. Adapun langkah-langkah yang dapat dilakukan dalam mengaplikasikan film sebagai media untuk mengarabkan sastra kepada peserta didik: (1) Pra Menonton kegiatan pra menonton ini guru dapat memulai pembelajaran dengan memberikan gambaran kepada peserta didik tentang kegiatan yang akan dilakukan, tujuan kegiatan, serta hal-hal mendasar yang terkait dengan film "Dilan 1990";(2) Kegiatan Menonton film, kegiatan ini dilakukan dengan memberikan lembar kerja yang harus diisi peserta didik sembari menononton film. Lembar kerja tersebut dapat berupa butir isian mengenai unsur-unsur naratif dalam film (3) Pasca menonton dengan meminta peserta didik untuk mendiskusikan lembar kerja untuk memberikan pandangan mengenai apa yang terkandung dalam film.
\end{abstract}

Kata kunci: film, media pembelajaran, pembelajaran sastra

\section{Pendahuluan}

Berbagai perkemngan media hiburan sudah banyak bemunculan. Salah satu dari media hiburan adalah film. Film merupakan suatu cerminan mentalitas suatu bangsa lebih dari media artistik lainnya. (Kacauer, 1974: 6). Pendapat tersebut bukan tanpa alasan, Kracauer melandaskan pernyataan tersebut dalam pendapatnya mengenai film dalam pembuatanya perlu memperhitungkan selera orang banyak. Dikarenakan memperhitungkan selera tersebut, maka film tidak dapat dilepaskan dari masyarakat penontonya. UU 33 tahun 2009 mengenai perfilman, menyatakan bahwa (1) film merupakan karya seni budaya yang memiliki peran strategis dalam meningkatkan ketahanan budaya bangsa dan kesejahteraan masyarakat lahir maupun batin untuk memperkuat ketahanan nasional. (2) film merupakan sarana pencerdasan bangsa, pengembangan potensi diri, pembinaan akhlak mulia, pemajuan kesejahteraan masyarakat, serta wahana promosi Indonesia di dunia Internasional. Selain dua manfaat diatas film juga mempunyai manfaat salah satunya menumbuhkan literasi visual. Tiemensma 
(2009:12) menyatakan bahwa literasi visual merupakan suatu kemampuan yang dilakukan untuk menafsirkan makna ilustrasi dari berbagai jenis media salah satunya adalah film atau dapat dikatakan bahwa literasi visual adalah suatu kemampuan dalam membaca gambar untuk selanjutnya diterima sebagai suatu pengalaman belajar. Menurut Moore dan Dwyer (1994: 101) menyatakan bahwa kemampuan literasi visual terdiri dari tiga konstruksi yaitu Visual thingking: kemampuan untuk mengorganisasi gambar yang ada dsekitarnya; Visual learning yaitu pada kemampuan penguasaan dan konstruksi pengetahuan sebagai suatu hasil interaksi gejara visual; Visual Communication adalah kemampuan untuk menggunakan simbol visual untuk menerjemahkan ide.

Tren yang terjadi akhir-akhir ini khususnya di perfilman Indonesia adalah pengadaptasian sebuah karya sastra kedalam sebuah film. Tentu kita mengetahui beberapa film yang diadaptasi dari novel kesebuah film layar lebar. Misalnya Laskar Pelangi, Sang Pemimpi, Manusia Setengah Salmon, Cinta Brontosaurus, Manusia Setengah Salmon, Dear Nathan, Ayat-Ayat Cinta, Cerita Cinta Di Pesantren, Hujan Dibulan Juni, Dilan 1990, dan masih banyak lagi. Awalnya, adaptasi film ini berlaku untuk karya sastra populer dan ringan. Namun seiring berjalanya waktu, karya sastra yang lebih serius pun menjadi bahan untuk diangkat menjadi sebuah film layar lebar. Misalya sang penari yang diangkat dari trilogi Ronggeng Dukuh Paruk karya Ahmad Tohari serta Mereka Bilang Saya Monyet yang diangkat dari dua cerpen karya Djenar Maesa Ayu yang berjudul Lintah dan Melukis Jendela. Hal tersebut tentunya membuat angin segar bagi karya sastra di Indonesia yang sebelumnya kurang diminati oleh masyarakat Indonesia.

Jika dilihat dari perspektif dalam pengembangan budaya, sastra dan film memang begitu terkait erat. Namun hal tersebut berbading terbalik dengan hubungan sastra dengan dunia pendidikan. Sastra di pendidikan Indonesia nampaknya kurang serasi. Hal tesebut dapat dilihat dari pembelajaran sastra yang dipandang sebelah mata di dunia pendidikan. Sepuluh tahun terakhir, dunia pendidikan di Indonesia disibukkan dengan perubahan model-model pengajaran yang begitu cepat. Berbagai perubahan kurikulum ini pun kemudian berimbas pada konsep-konsep pengajaran sastra di sekolah yang diharuskan untuk berpijak pada desain-desain yang sudah ada (Rohman, 2012: 13). Materi yang begitu sedikit ditambah pembelajan diintegrasikan dengan bahasa, secara tidak langsung akan membuat pembelajaran sastra mengikuti titik berat pada kompetensikompetnsi yang ada dalam kuikulum, sehingga membuat tujuan pembelajaran sastra tidak dapat tercapai. Pembelajaran sasta memang tidak dapat dipisahkan dari pembelajaran bahasa. Namun, pembelajaran sastra tidaklah dapat disamakan dengan pembelajaran bahasa. Perbedaan ini terletak pada tujuan akhirnya.

Pembelajaran sastra pada dasarnya mengembangkan aspek afektif peserta didik, yaitu memperkaya pengalaman peserta didik dan menjadikanya tanggap terhadap peristiwa-peristiwa disekelilingnya. Tujuan akhir pembelajaran sastra adalah menanamkan, menumbuhkan, dan mengembangkan kepekaan terhadap masalah-masalah kemanusiaan, pengenalan dan rasa hormat terhadap nilai yang baik dalam konteks inividual maupun sosial (Oemarjati, 1992:196). Pembelajaran sastra yang ideal merupakan pembelajaran yang menumbuhkan inovasi yang sarat 
akan kreativitas, maka sangat penting bagi pembelajaran sastra untuk melakukan berbagai cara kreatif dalam pembelajaranya sehingga dapat membuat peserta didik berminat untuk mempelajari karya sastra. Pembelajaran karya sastra ini tidak terbatas pada membaca serta memahami suatu karya sastra melainkan juga mengapresiasi sastra.

Akhir-akhir ini ada sebuah film yang begitu populer yang berkisah tentang percintaan remaja di masa SMA. "Dilan 1990" merupakan film yang diadaptasi dari sebuah novel karya Pidi baiq. Film ini menceritakan kisah tokoh yang bernama Milea, siswa pindahan dari Jakarta yang bertemu dengan Dilan di sebuah SMA di Bandung. Latar waktu yang diambil baik dalam novel mapupun di filmnya adalah tahun 1990. Cerita yang dikemas begitu kreatif dan dekat dengan dunia generasi muda khususnya pada dunia SMA membuat film ini dapat mengambil hati baik penontonnya, sehingga berdampak pula pada minat masyarakat untuk menikmati karya sastra berupa novel yang berjudul sama dengan adaptasi filmnya. Dengan adanya banyaknya novel yang diadaptasi dalam sebuah film diharapkan menjadi jawaban terhadap minat masyarakat terhadap karya sastra itu sendiri. Selain itu, film adaptasi bisa jadi dapat menjadi alternatif untuk merangsang kreatifitas peserta didik untuk mempelajari karya sastra.

Berdasarkan uraian diatas, tujuan dari penelitian ini adalah memahami sejauhmana aktualisasi pembelajaran film khususnya film "Dilan 1990" menjadi media mengakrapkan peserta didik terhadap karya sastra. Tulisan ini tidak dikhususkan pada tingkat pendidikan tertentu. Namun pada bagaimana tulisan ini dapat menjadi manfaat bagi pelaku pendidikan untuk mengembangkan media pembelajaran sastra sebagai salah satu sarana untuk mencapai tujuan pemebelajaran sastra. selain itu, manfaat lain dari artikel ini adalah dapat dijadikan sebagai salah satu referensi pengampu pendidikan dalam merencanakan pembelajaran khususnya media pembelajaran dalam mengakrapkan sastra kepada peserta didik.

\section{Pembahasan}

Sebelum membahas mengenai hubungan antara sastra dan film adaptasi "Dilan 1990" ada baiknya kita mengentahui hakikat sastra dan film terlebih dahulu. Sastra sebenarnya sudah muncul dari ratusan tahun yang lalu. Waren dan Wellek (1993: 1) mengemukakan bahwa sastra adalah suatu kegiatan kreatif, sebuah karya seni. Danziger dan Jhonson dalam (Budiman, 2002:7) menyatakan bahwa sastra merupakan seni bahasa yaitu cabang dari seni yang menggunakan bahasa sebagai medianya. Sedangkan karya sastra menurut Damono (1984: 1) diciptakan sastrawan untuk dinikmati, dipahami, dan dimanfaatkan oleh masyarakat. Jadi dari ketiga pendapat para ahli diatas dapat disimpulkan bahwa karya sastra merupakan hasil dari kegiatan kreatif sastrawan dan menempatkan bagian dari karya seni yang memiliki fungsi penciptaan. Fungsi dari penciptaan ini adalah untuk dinikmati, dipahami dan dimanfaatkan bagi masyarakat baik berupa pengetahuan, wawasan, bahkan sejarah atau bisa dikatakan bahwa sastra mempunyai fungsi menghibur dan bermanfaat bagi masyarakat. Dikatakan menghibur karena sastra memberikan rasa indah serta menumbuhkan imanjinasi yang terkandung dalam setiap makna kata dalam setiap tulisan terkait dengan 
berbagai masalah-masalah dalam kehidupan. Sedangkan manfaat yang diberikan oleh karya sastra adalah berupa gagasan, perasaan yang diibaratkan sebagai potret kehidupan. Melalui fungsi tersebut tidak jarang karya sastra juga digunakan sebagai cara atau sarana dalam melakukan kritis sosial.

Film hakikatnya merupakan suatu bentuk ekspresi yang berbentuk permainan gambar, bunyi, dan gerakan yang saling menyatu dan berkesinambungan. Boogs dan Denis (2008:3) sendiri memandang bahwa film mempunyai kemiripan dari berbagai bentuk seni lain salah satunya adalah sastra. Senada dengan hal tersebut, Allen dan Gomery (1985: 37) menyatakan bahwa film adalah more than one thing, certainly more than a collection of individual films; it is a set of complex, interactive system of human communication, business practice, social interaction, artistic possibilities, and technology. Pada mengertian yang diungkapkan Allen dan Gomery ini, film melibatkan banyak hal yang kompleks misalnya melibatkan seniman dari berbagai cabang salah satunya adalah seni sastra. Film mempunyai fungsi yang pertama untuk menghibur dan yang kedua adalah fungsi deductism (Winokur, 2001 8-9). Deductism merupakan teks yang maknanya seringkali mengacu ada konteks sosial, politik, etika, agama, dan budaya. Dari dua fungsi diatas, terlihat jelas bahwa film mempunyai kesamaan sebagaimana karya sastra.

Monaco (2005:44) menghubungkan film dengan karya sastra berupa novel dan mengatakan bahwa potensi naratif dalam sebuah film begitu penting sebagaimana dengan novel. Keterkaitan pada suatu novel ataupun film terlihat dari sisi naratifnya, dimana baik film maupun novel dapat menceritakan suatu kisah secara detail dari sudut pandang penulisnya. Hal yang diceritakan dalam novel dapat digambarkan didalam suatu film, meskipun untuk melakukanya diperlukan banyak efek. Bogs dan Denis (2008: 4) mengatakan bahwa sastra dan film mempunyai banyak kesamaan dalam elemenya. Bahkan bisa dikatakan analisis film tergantung pada prinsip-prinsip yang digunakan dalam analisis sastra. Hal tersebut dapat diartikan bahwa unsur naratif yang terdapat dalam film sama dengan apa yang dimiliki oleh sebuah karya sastra dalam hal ini adalah novel.

Dari penjelasan para ahli diatas tampaknya sudah cukup dijadikan landasan mengenai memanfaatkan film adaptasi dengan judul "Dilan 1990" sebagai media pembelajaran sastra. Dilan 1990 merupakan sebuah film yang diadaptasi dari sebuah novel berseri karangan Pidi Baiq. Kisah yang diangkat dalam film ataupun novel karangan Pidi Baiq serta sutradara Fajar Bustomi ini mengangkat kisah cinta antar remaja di masa SMA yaitu Milea sebagai wanita remaja yang baru pindah dari Bandung dengan Dilan seorang siswa yang dianggap nakal dan arogan karena bergabung dengan gank motor dan menjadi panglima tempur dalam gank tersebut. Kisah cinta yang romantis namun menggelitik membuat film ini mendapatkan tempat dimasyarakat tidak terkecuali peserta didik.

Tidak hanya kisah cinta yang romantis dan menggelitik, namun terdapat unsur lain yang membuat penulis tertarik menjadikan film "Dilan 1990" menjadi media pembelajaran sastra. Unsur-unsur lain yang membuat penulis tertarik untuk menjadikan film "Dilan 1990" menjadi media pembelajaran sastra antara lain adanya pertama nilai pendidikan misalnya dalam adegan seorang tokoh yang bernama Suripto memukul tokoh Dilan yang tidak lain adalah seorang siswa. Nilai pendidikan yang muncul dalam adegan ini adalah kekerasan kepada anak tidak 
dapat dibenarkan walaupun siswa tersebut dianggap nakal serta kalimat tokoh Dilan yang muncul pada adega tersebut yaitu "guru digugu lan ditiru" artinya seorang guru adalah sosok yang seharusnya menjadi panutan bagi siswanya bukan malah memberikan penanganan yang buruk sehingga menimbulkan dampak negatif dari kelakukan atau penanganya yang salah terhadap peserta didik. Nilai pendidikan lain yang ada dalam film dan novel ini adalah pada adegan dimana penanganan yang dilakukan oleh orang tua tokoh Dilan yang tidak menonjolkan arogansi kepada anaknya dalam mendidik walaupun anaknya dianggap nakal oleh para gurunya. Kedua nilai moral yang ditujukan dalam film dan novel karangan Pidi Baiq adalah bagaimana penanganan tokoh Dilan yang dianggap nakal namun tetap sopan baik pada orang tuanya dan para guru yang mengajarnya. Ketiga tata bahasa yang kreatif serta kisah yang diangkat dalam film ini begitu akrab dengan peserta didik karena mengisahkan kehidupan remaja di masa SMA. Hal tersebut dilakukan untuk menarik minat perserta didik dalam pembelajaran sastra serta meningkatkan rasa penasaran untuk membandingkann film dengan karya sastra, dengan begitu secara tidak langsung akan menumbuhkan antusiasme peserta didik dalam mempelajari sastra melalui membandikan film dengan karya sastra yang diadaptasi.

Walaupun dalam kenyataanya mengadaptasian film banyak mengurangi esensi karya sastra, namun hal tersebut dapat dijadikan sebuah gagasan untuk membawa peserta didik dalam membaca novel dan berpikir kritis dalam penggunaan film sebagai media pembelajaran sastra. Misalnya peserta didik diajak berpikir kenapa dalam film tersebut dibuat dengan alur yang berbeda atau mengapa karakter dalam film mengelami pergeseran dibanding dengan novel atau kenapa akhir cerita dalam film dibuat berbeda dari novel aslinya.

\section{Film Adaptasi "Dilan 1990" Sebagai Media Mengakrabkan Peserta didik Terhadap Karya Sastra}

Berbicara mengenai bagaimana mengakrabkan sastra dengan peserta didik, maka tidak dapat dilepaskan dari bagaimana proses pembelajaran yang dilakukan didalam kelas. Guru yang dianggap sebagai pendamping dalam pembelajaran perlu memikirkan cara-cara untuk bagaimana pembelajaran tersebut dapat menarik untuk dipelajari oleh peserta didik sehingga menimbulkan keakraban peserta didik dan karya sastra itu sendiri.

Pendidikan formal pada hakikatnya bertujuan untuk mengembangkan potensi peserta didik sesuai dengan dengan kemampuanya yang berhubungan dengan kecerdasan, kejujuran, keterampilan, pengenalan kemampuan, serta pembinaan watak peserta didik (Oemarjati. dkk, 1992: 198). Salah satu komponen pendidikan formal disini adalah pembelajaran sastra. Secara khusus Oemarjati dkk (1992:198) mengatakan bahwa pembelajaran sasta bertujuan dalam mengembangkan kepekaan peserta didik terhadap nilai indrawi, nilai afektif, nilai sosial, ataupun gabungan dari seluruhnya. Maka dari itu sastra perlu diajarkan kepada peserta didik.

Terdapat tiga hal utama yang perlu diperhatikan dalam pembelajaran karena proses pembelajaran merupakan proses komunikasi yang melibatkan pemberi pesan dalam hal ini adalah guru, pesan itu sendiri dalam hal ini adalah materi 
pembelajaran sastra, dan penerima pesan dalam hal ini adalah peserta didik, maka dapat dikatakan bahwa dalam keefektifan proses pembelajaran ditentukan oleh corak komunikasi yang terjalin antara guru, materi, dan peserta didik. Maka untuk membantu proses komunikasi antara guru, materi, dan peserta didik tersebut memerlukan suatu suatu media pembelajaran. Media pembelajaran sendiri menurut Sadiman dkk (2012: 7) adalah segala sesuatu yang dapat digunakan untuk menyalurkan pesan dari pengirim ke penerima sehingga dapat merangsang pikiran, perasaan, perhatian, dan minat serta perhatian siswa sedemikian rupa sehingga proses belajar terjadi. Dari definisi ini dapat kita tarik dua fungsi penting mengenai media. Pertama, media merupakan alat komunikasi. Kedua, media diharapkan menjadi stimulus siswa agar dapat menumbuhkan minat belajar. Sadirman dkk (2012: 7) juga menyebutkan setidaknya 4 kegunaan dari media pembelajaran.

1. Memperjelas penyajian pesan agar tidak terlalu verbalistis.

2. Mengatasi keterbatasan ruang, waktum dan daya indra.

3. Mengatasi sifat pasif peserta didik.

4. Menyamakan stimulus, pengalaman, dan persepsi.

Hal yang sering terjadi dalam pembelajaran khususnya dalam pembelajaran sastra adalah hampir semua kegiatan yang dilakukan dalam pembelajaran bersifat verbal sehingga menjauhkan esensi sastra itu sendiri dari peserta didik. Melalui asumsi tersbut, guru perlu berpikir kreatif untuk bagaimana pembelajaran sastra dapat diakrapkan pada peserta didik sehingga akan mempermudah peserta didik dalam memahami materi sastra itu sendiri. Kunci dalam membuka keakraban peserta didik dengan sastra adalah bagaimana penyampaian guru terhadap materi sastra itu sendiri. Penyampaian guru terhadap materi sastra yang kreatif salah satunya melalui media pembelajaran akan menimbulkan keterbukaan peserta didik dengan keluguanya dalam mengarabkan diri terhadap karya sastra, sebaliknya jika penyampaian materi sastra kurang kreatif akan menimbulkan efek menjauhnya peserta didik terhadap materi sastra itu sendiri, bahkan tidak jarang peserta didik akan acuh terhadap materi sastra. Tanpa adanya keakraban materi sastra kepada peserta didik, sulit dibayangkan kemungkinan terwujudnya tujuan dari pembelajaran sastra itu akan tercapai. Selain itu, masalah yang kerap ditemui dalam kegiatan pembelajaran sastra disekolah antara lain:

1. Keterbatasan jumlah buku sastra yang tersedia.

Tentu kita sudah mengetahui bahwa buku-buku yang ada disekolah banyak didominasi dengan buku-buku meteri pelajaran seperti buku materi-materi pelajaran yang mendukung dalam ujian baik dalam ujian sekolah, ujian semester, dan ujian nasional. Jarang sekali ditemui buku-buku sastra yang ada disekolah. Bahkan tidak jarang para guru memandang buku-buku sastra tersebut menganggu untuk dijadikan sebagai buku bacaan karena dirasa tidak mendukung terhadap ujian yang akan dilakukan disekolah sehingga menimbulkan minat baca khususnya dalam membaca karya sastra rendah. 
2. Kurikulum yang mengutamakan materi pembelajaran yang tidak berpihak sastra.

Sistem kurikum yang tidak berpihak pada pembelajaran sastra; ketersediaan buku teks sastra yang terbatas; sistem evaluasi tidak mengakrabkan siswa pada karya sastra tetapi beralih kepada lembaga bimbingan tes; pendekatan, strategi, dan metode yang digunakan dalam pembelajaran sastra yang hanya mengarahkan siswa pada dimensi pengetahuan (hafalan) tentang sastra dan bukannya pengalaman mereka bersastra.

3. Peseta didik tidak mempunyai cukup waktu untuk membaca karya sastra

Tidak dapat dipungkiri bahwa beban belajar peserta didik pada masa sekarang jauh lebih banyak dibandingkan terdahulu. Beban belajar yang cenderung mengarahkan peserta didik untuk mensuseskan ujian baik dalam ujian harian, ujian semester, dan ujian nasional menilbulkan banyaknya sistem drill digunakan disekolah. Hal tersebut secara tidak langsung membuat peserta didik tidak mempunyai waktu dalam membaca karya sastra sehingga pengalaman dan persepsi dalam memahami karya sasta kurang.

Penggunaan film adaptasi yang berjudul "Dilan 1990" sebagai media pembelajaran sastra merupakan salah satu cara untuk mengatasi berbagai masalah tersebut dan mengakrabkan sastra dengan perbedaan gaya belajar peserta didik. Pertama Penggunaan film "Dilan 1990" ini secara tidak langsung akan membuat peserta didik tertarik untuk membaca karya sasta tanpa paksaan, melainkan murni dari keingginan peserta didik itu sendiri. Tentu kita mengetahui bahwa suatu hal yang dilanadsi karena niat probadi akan jauh lebih menghasilkan dari pada suatu paksaan. Kedua dengan adanya minat baca peserta didik secara tidak langsung akan dapat menyelipkan materi dan tujuan sastra yang tidak dapat diakomodir dari sistem kurikulum yang berlaku. Ketiga dapat mempersingkat waktu dalam kaitan persamaan persepsi dan pengalaman memahami karya sastra. Melalui penggunakan film yang berjudul "Dilan 1990" secara tidak langsung akan akan memberikan stimulus terhadap peserta didik dalam pengalaman dan persepsi akan karya sastra lebih merata, jika pun terdapat perbedaan maka hal tersebut dapat diatasi melalui kegiatan disukusi dalam kelas. Selain ketiga hal tersebut, penggunaa media film adapatsi yang berjudul "Dilan 1990" dapat mengakomodasi gaya belajar peserta didik yang berbeda.

Peserta didik yang mempunyai gaya belajar visual pasti akan terakomodasi dengan tampilan visual film sedangkan peserta auditorial akan terakomodasi dengan bahasa verbal film. Peserta didik yang kinestetik akan terakomodasi dengan pergerakan audiovisual yang mempunyai sifat menstimulus suatu realitas yang nyata. Melalui hal tersebut, maka penggunaan film dalam hal ini film adaptasi berjudul "Dilan 1990" adalah hal yang cukup bermanfaat dalam memfasilitasi peserta didik dalam memahami dan mengakrabkan peserta didik dalam pembelajaran sastra ditengah permasalahan terkait dengan kegiatan pembelajaran sastra yang ada di sekolah. 


\section{Aplikasi Film "Dilan 1990" dalam Pembelajaran Sastra}

Pada sub bab ini penulis akan menjelaskan mengenai aplikasi film "Dilan 1990" dalam pembelajaran sastra. Namun sebelumnya perlu diingat bahwa yang akan dijelaskan bukan merupakan prosedur yang baku dan harus diikuti serta metode dengan menggunakan media film "Dilan 1990" tidak harus selalu dilakukan dalam pembelajaran sastra. gagasan ini dilakukan hanya untuk memberikan pengetahuan bagi pelaku pendidikan dalam memvariasi proses pembelajaran yang bertujuan untuk mengakrapkan sastra kepada peserta didik.

Tentu kita mengetahui ada empat aspek dalam pembelajan bahasa yaitu menyimah, membaca, berbicara, menulis. Kegiatan pembelajaran menggunakan media film adaptasi yang berjudul "Dilan 1990" ini dapat dikatakan dapat memenuhi aspek membaca dan menyimak. Pada kegiatan pembelajaran menggunakan media film adaptasi yang berjudul "Dilan 1990" penulis membagi tiga bagian proses pembelajaran.

1. Pra Menonton

Pada kegiatan pra menonton ini guru dapat memulai pembelajaran dengan memberikan gambaran kepada peserta didik tentang kegiatan yang akan dilakukan, tujuan kegiatan, serta hal-hal mendasar yang terkait dengan film "Dilan 1990". Hal mendasar yang dimaksud adalah latar waktu, latar tempat, nilai pendidikan, nilai moral yang diangkat dari film tersbut. Misalnya guru bisa memulai dengan gambaran mengenai sejarah kota Bandung di era 90an yang menjadi latar tempat dan waktu film tersebut, jika memungkinkan ajaklah peserta didik untuk membicarakan mengenai nilai pendidikan dan nilai moral untuk memancing rasa keingintahuan peserta didik sebelum menonton film tersebut.

2. Kegiatan Menonton film

Kegiatan menonton ini memerlukan adanya kreatifitas guru karena dalam proses menonton ini siswa akan cenderung pasif, sehingga proses pembelajaran dalam kegiatan menonton ini memerlukan kreatifitas guru agar peserta didik dapat memfokuskan pada hal yang utama dalam film. Hal tersebut dapat dilakukan dengan memberikan lembar kerja yang harus diisi peserta didik sembari menononton film. Lembar kerja tersebut dapat berupa butir isian mengenai unsurunsur naratif dalam film tersebut baik tokoh, alur, dan latar yang ada dalam film dan seterusnya

3. Pasca Menonton

Setelah melakukan kegiatan menonton, peserta didik diberikan waktu untuk menyelesaikan lembar kerjanya. Selanjutnya guru bisa meminta peserta didik untuk mendiskusikan lembar kerja untuk memberikan pandangan mengenai apa yang terkandung dalam film. Selain itu, melalui kegiatan diskusi tersebut guru dapat melihat keaktifan peserta didik. Setelah semua kegiatan dilakukan guru dapat merefleksikan kegiatan yang dilakukan selama melakukan proses pembelajaran. Kegiatan refleksi ini dapat berupa pertanyaan yang dilontarkan guru kepada peserta didik misalnya:

a) Karakter mana yang paling disukai? Mengapa?

b) Memberikan gambaran secara nyata melalui pertanyaan, jika kalian menjadi tokoh D dalam adegan tertentu dalam film apa yang kalian lakukan sesuai dengan nilai-nilai yang ada dalam masyarakat? 
c) Nilai apa saja yang dapat kalian ambil dalam cerita tersebut?

d) Memberikan pengertian bahwa film tersebut diangkat dari sebuah novel, maka guru dapat memberi pertanyaan untuk memberikan stimulus kepada peserta didik untuk membaca novel tersebut. Misalnya dengan memberikan pertanyan "apakah kalian tertarik untuk membaca novel tersebut?

Kegiatan menonton film adaptasi yang berjudul "Dilan 1990" ini memang tidak dapat mewakili kegiatan membaca suatu karya sastra, karena memang bentuk produksi yang berbeda. Oleh karena itu, kegiatan menonton film adaptasi ini dapat dibarengi dengan membaca karya sastra yang terkait dalam hal ini adalah novel Dilan 1990. Untuk mengakhiri kegiatan tersebut guru dapat memberikan suatu kegiatan untuk membuat resensi novel dengan standart yang ditentukan oleh guru. Tentu untuk tugas ini guru perlu memberikan apresiasi bagi peserta didik yang dapat memenuhi standar atau bahkan lebih dari standar. Kesemuanya kegiatan tersebut digunakan untuk menumbuhkan kearaban peserta didik dalam mempelajari karya sastra.

\section{Kesimpulan}

Karya sastra dan film adaptasi mempunyai fungsi yang hamper sama yaitu menghibur dan memberikan suatu manfaat serta wawasan terhadap pembaca ataupun penonton. Selain itu baik novel dan film adaptasi mempunyai unsur narasi yang dapat ditemukan pada keduanya. Maka antara sasta dan film adaptasi mempunyai kedekatan yang erat. Kedekatan inilah yang membuat karya sastra seringkali diadaptasi menjadi sebuah film layar lebar. Melihat dari kedekatan tersebut, maka film dapat dijadikan sebagai media pembelajaran sastra yang efektif dan efisien dengan berbagai perbedaan gaya belajar peserta didik. Adapun langkah-langkah yang dapat dilakukan dalam mengaplikasikan film sebagai media untuk mengarabkan sastra kepada peserta didik: (1) Pra Menonton kegiatan pra menonton ini guru dapat memulai pembelajaran dengan memberikan gambaran kepada peserta didik tentang kegiatan yang akan dilakukan, tujuan kegiatan, serta hal-hal mendasar yang terkait dengan film "Dilan 1990";(2) Kegiatan Menonton film, kegiatan ini dilakukan dengan memberikan lembar kerja yang harus diisi peserta didik sembari menononton film. Lembar kerja tersebut dapat berupa butir isian mengenai unsur-unsur naratif dalam film (3) Pasca menonton dengan meminta peserta didik untuk mendiskusikan lembar kerja untuk memberikan pandangan mengenai apa yang terkandung dalam film.

\section{Daftar Pustaka}

Allen, R. C. \& Douglas, G. (1985). Film history theory and practice. USA: McGraw-Hill, Inc.

Boggs, J. M. P. \& Dennis, W. (2008). The art of watching films. New York: McGraw-Hill.

Budianta, M., dkk. (2002). Membaca sastra (Pengantar memahami sastra untuk perguruan tinggi). Jakarta: Indonesia Tera.

Damono, S. D. (1984). Sosiologi sastra: Sebuah pengantar ringkas. Jakarta: Pusat Pembinaan dan Pengembangan Bahasa. 
Kracauer, S. (1974). From Cagliari to Hitler: A psychological history of the German film. New Jersey: Princeton University Press .

Monaco, J. (2005). How to read a film: The world of movies, media, and multimedia. New York, Oxford: Oxford University Press.

Moore, D., Francis, M., \& Dwyer, M. (1994). Visual literacy: A spectrum of visual learning. Engelewood Cliffs, NJ: Educatonal Technology Publications.

Oemarjati, B. S. (1992). Dengan sastra mencerdaskan siswa: Memperkaya pengalaman dan pengetahuan. Jakarta: Pustaka Sinar Harapan.

UU Nomor 33 Tahun 2009 tentang Perfilman. http://jdih.kemenpar.go.id/dokumen/file-pdf/5168_1434UU33Tahun2009Perfilman.pdf.pdf.

Rohman, S. (2012). Pengantar metodologi pengajaran sastra. Yogyakarta: ArRuzz Media.

Sadiman, A. S., dkk. (2005). Media pendidikan: Pengertian, pengembangan, dan pemanfaatannya. Jakarta: PT Raja Grafindo Persada.

Tiemesma, L. (2009). Visual literacy: To comic or not? Promoting literacy pushing comic. Milan: IFLA.

Winokur, M. \& Holsinger, B. (2001). The complete idiot's guide to movies, flicks, and films. Indianapolis: Alpha Books.

Wellek, R. \& Austin, W. (1993). Teori kesusastraan, diterjemahkan oleh Melani Budianta. Jakarta: Gramedia. 